\title{
Enzymatic activity of proteases and its isoenzymes in fermentation process in cultivars of cocoa (Theobroma cacao L.) produced in southern Bahia, Brazil
}

\author{
Luciane Santos SOUSA ${ }^{1 *}$, Fátima de Souza ROCHA ${ }^{1}$, Paulo Túlio de Souza SILVEIRA ${ }^{1}$, Eliete da Silva BISPO ${ }^{1}$, \\ Sérgio Eduardo SOARES ${ }^{1}$
}

\begin{abstract}
The fermentation of cocoa seeds envolves microbial processes and the action of enzymes. To identify the possible differences in the cocoa fermentation process, with regards to proteolysis, this study has the objective of determining protease activity (under predetermined conditions) and its isoenzymes in two cocoa cultivars (PH-16 and HRT-1188) in different cocoa fermentation times, in addition to establishing the microbial load (molds and yeasts and aerobic mesophilic). Protease and its isoenzymes were extracted and partially purified and the enzymatic activities determined by spectrophotometry. The results showed that the proteases activity was higher at $66 \mathrm{~h}$ of fermentation for both cultivars. When the isoenzymes activity was evaluated, the results demonstrated similar activity behavior for both cultivars, with regards to the isoenzymes aminopeptidase and carboxypeptidase, although the behavior of the endoprotease isoenzyme activity proved to be a little different for TSH-1188 cultivar. Concerning microbiological analyses, the results indicate that the period after molds and yeast counting reduction is consistent with the period of protease activity increase.
\end{abstract}

Keywords: cocoa; proteolysis; aminopeptidase; carboxypeptidase; endoprotease.

Practical Application: This study evaluates proteases enzymatic activity and their isoenzymes under predetermined conditions in the cocoa fermentation process, highlighting the importance of proteolysis in the formation of precursors of cocoa flavour and therefore chocolate.

\section{Introduction}

Cacoa (Theobroma cacao L.) is cultivated in tropical regions around the world. Its fruit is the main ingredient in chocolate production and in its derivatives, becoming an important component in the economy of many countries including Brazil. Bahia stands out as one of the largest cocoa-producing state in Brazil (Ardhana \& Fleet, 2003; Lopes et al., 2011).

The cocoa seeds and pulp are removed manually after opening the fruit and immediately contaminated by different microorganisms that predominate in the environment. The pulp is rich in carbohydrates, that serve as substrates for micro-organisms during the fermentation process, and this key step, in the post-harvest processing, is generally performed in a traditional manner (Ardhana \& Fleet, 2003; Camu et al., 2007, 2008a, b; De Vuyst et al., 2010; Garcia-Armisen et al., 2010; Jespersen et al., 2005; Nielsen et al., 2007; Papalexandratou et al., 2011a, b, c.; Schwan \& Wheals, 2004; Thompson et al., 2001; Wood \& Lass, 2001).

This spontaneous phenomenon (fermentation) is carried out by the successive action of natural micro-organisms from the environment (Cruz et al., 2013). As a result of microbial action, the envelope pulp of cocoa beans is degraded, yielding metabolites as final products including alcohols and organic acids, which diffuse through the membrane and, in combination with increased temperature, promotes the death of the germ (embryo). These changes induce, in turn, a series of complex biochemical reactions inside and outside almonds, generating precursors (free amino acids, peptides and reducing sugars) flavor and cocoa flavor (Afoakwa et al., 2008; Beckett, 2009; Daniel et al., 2009; De Vuyst et al., 2010; Fowler, 2009; Hansen et al., 1998; Schwan \& Wheals, 2004; Thompson et al., 2013).

Currently, studies show that reactions which lead to the formation of cocoa flavor precursors are conducted by endogenous enzymes present in cocoa seeds (Afoakwa et al., 2008; Beckett, 2009). However, at the same time, other researchers believe that enzymes derived from micro-organisms metabolism also have importance in the development of cocoa flavor precursors and therefore chocolate (Levanon \& Rossetini, 2001).

Although the essential role of endogenous enzymes during fermentation has been evidenced many years ago, there is still a lack of systematic studies addressing the comparison between different cocoa cultivars (Hansen et al., 1998). It is known, however, that proteases, in order to carry out proteolysis, produces precursors (peptides and free amino acids) which together with reducing sugars, participate in Maillard reactions during roasting of the 
beans, thereby contributing to the development of cocoa flavor and aroma (Huang \& Barringer, 2010; Voigt et al., 1994a, b).

Studies have seeked to determine the influence of external factors on the cocoa fermentation process in order to reach better quality final products. (Camu et al., 2007, 2008a; Nielsen et al., 2007; Schwan, 1998). However, one of the main difficulties in assessing differences between cocoa varieties comparatively is the lack of studies that used distinct materials subjected to the same fermentation protocols, drying and roasting (Bucheli et al., 2000; Efraim et al., 2006).

Considering the above, this study aimed to determine the enzymatic activity of proteases (under predetermined conditions of temperature, $\mathrm{pH}$ and substrate concentration) and its isoenzymes in different fermentation times of two cocoa cultivars (PH-16 and TSH-1188) produced in the South of Bahia, Brazil, and to establish the microbial load related to mold and yeasts and aerobic mesophilic. It also has the purpose of expanding the scientific knowledge on proteolysis in cocoa fermentation so as to provide a basis for future technological interventions linked to enzymatic biotechnology, thereby contributing to the improvement of raw material quality in chocolate production.

\section{Materials and methods}

\subsection{Material}

Two cacoa cultivars were studied, $\mathrm{PH} 16$ and TSH-1188, produced

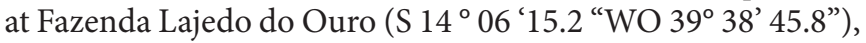
in the south of the state of Bahia, Brazil. The material under study was donated by producers according to their availability in the period of the experiment.

\subsection{Methods}

Fermentation of cacoa cultivars (PH-16 and TSH-1188)

The fermentation was conducted in wooden troughs containing holes of $1.27 \mathrm{~cm}$ diameter to allow the flow of fluid produced during fermentation. The step of fermentation was monitored for seven days for the $\mathrm{PH}-16$ cultivar and six days for the TSH-1188. However, the revolvement of cocoa mass in the troughs was performed at different times for the two cultivars, the $\mathrm{PH}-16$ was revolved every $48 \mathrm{~h}$ and the TSH-1188 every $24 \mathrm{~h}$.

\section{Sample collection}

Samples were collected at different fermentation times until the end of the process for both cultivars (PH-16 and TSH-1188), a total of ten (10) samples for each cultivar.

\section{Extraction of proteases from pulp and seeds}

The proteases extraction was performed as described by Gomez et al. (1999) using $100 \mathrm{~g}$ cocoa beans, from which pulps were manually removed and then immersed in $0.1 \mathrm{M}$ Tris- $\mathrm{HCl}$ $\mathrm{pH} 7.5$ buffer in the ratio $1: 2(\mathrm{w} / \mathrm{v})$ and then triturated and homogenized at $4{ }^{\circ} \mathrm{C}$. The homogenate was centrifuged at $4{ }^{\circ} \mathrm{C}$ for 10' (Hitachi, model CR22GIII) at 20,000 $\times \mathrm{g}$. The supernatant (extract) was stored in a freezer at $-18^{\circ} \mathrm{C}$ until the completion of the partial purification. The seeds that were manually removed were lyophilized (Lyophilizer Liotop, Model L108) and then crushed and defatted with petroleum ether (Yusep et al., 2002), then treated with acetone as described by Hansen et al. (1998). After solvent evaporation, the powder of the treated seed was suspended in $0.2 \mathrm{M}$ sodium phosphate buffer $\mathrm{pH} 7.5$ at $4{ }^{\circ} \mathrm{C}$ in the ratio $1: 5(\mathrm{w} / \mathrm{v})$ and homogenized with a magnetic stirrer at $4{ }^{\circ} \mathrm{C}$ for 30 '. After mixing, the suspension was centrifuged at $20,000 \times \mathrm{g}$ at $4^{\circ} \mathrm{C}$ for $10^{\prime}$, and the supernatant reserved for the partial purification phase (Misnawi et al., 2002).

Partial purification of pulp and seeds proteases

Partial purification was performed according to Deuner et al. (2005) by adding ammonium sulfate [(NH4) 2SO4] (80\% saturation) to the extracts slowly, with gentle stirring at $4{ }^{\circ} \mathrm{C}$, followed by centrifugation at $20,000 \times \mathrm{g} 4^{\circ} \mathrm{C}$ for 60 , reserving the precipitate. The pulp extracts were dialyzed for $24 \mathrm{~h}$ at $4{ }^{\circ} \mathrm{C}$ against Tris- $\mathrm{HCl}$ buffer $0.01 \mathrm{M} \mathrm{pH} 7.5$ ) and seed extracts were dialyzed for $48 \mathrm{~h}$ at $4{ }^{\circ} \mathrm{C}$ against sodium phosphate buffer $0.2 \mathrm{M} \mathrm{pH} 7.5$, cellulose membranes $(43 \mathrm{~mm})$ have been used for both, obtaining then, partially purified enzyme extracts (Silva et al., 2003).

\section{Protease activity determination (Pulp and Seeds)}

The proteases activity was determined by taking aliquots of $100 \mu \mathrm{L}$ of the partially purified extract, by adding $100 \mu \mathrm{L}$ of sodium phosphate buffer $0.1 \mathrm{M} \mathrm{pH} 5,7$ (pulp) and sodium citrate buffer $0.1 \mathrm{M} \mathrm{pH} \mathrm{3,1} \mathrm{(seed).} \mathrm{To} \mathrm{this} \mathrm{mixture} \mathrm{it} \mathrm{was} \mathrm{added} 100 \mu \mathrm{L}$ of substrate, then incubated at $50^{\circ} \mathrm{C}$ (pulp) and $31^{\circ} \mathrm{C}$ (seed) for the two cultivars for 30 '. The reaction was stopped by adding $500 \mu \mathrm{L}$ of trichloroacetic acid (TCA) at 10\%. Then centrifuged at $10,000 \mathrm{x}$ g for $5^{\prime}$ and then added to the supernatant $200 \mu \mathrm{L}$ of $\mathrm{NaOH} 1.8 \mathrm{~N}$. Reading was taken using a spectrophotometer (Biochrom, Model Libra S50) at 280nm. For quantification, an enzymatic unit was considered as the amount of enzyme required to increase the absorbance in 0,01 . A control was used with the addition of TCA prior to sample incubation (Giongo, 2006).

\section{Endoprotease activity determination (Pulp and Seeds)}

To determine the endoprotease activity, aliquots of $500 \mu \mathrm{L}$ of the partially purified extract were incubated at $45^{\circ} \mathrm{C}$ for $30^{\prime}$ with a mixture containing $20 \mathrm{mg}$ of bovine albumin and $2.0 \mathrm{~mL}$ of phosphate buffer $0.2 \mathrm{M}, \mathrm{pH} 3.5$. The reaction was stopped by adding $0.5 \mathrm{~mL}$ of TCA at $20 \%$, then centrifuged at $10,000 \times \mathrm{g}$ for 15' (Amin et al., 1998; Hansen et al., 1998). The amount of proteolytic products was determined by ninhydrin reaction, mixing $400 \mu \mathrm{L}$ of the supernatant with $400 \mu \mathrm{L}$ of the ninhydrin reagent. The mixtures were incubated for 15' (boiling water bath) and cooled in ice, then added $1 \mathrm{~mL}$ of ethanol (50\%), quickly mixed, and the absorbance measured at $570 \mathrm{~nm}$. An endoprotease unit was considered as the amount of enzyme required for releasing $1 \mathrm{mmol}$ of amino groups per minute. L-Leucine was used as the standard (Misnawi et al., 2002; Hansen et al., 1998).

\section{Carboxipeptidase activity determination (Pulp and Seeds)}

A solution of $1 \mathrm{ml}$ of the partially purified extract was incubated with Pepstatin A $(10 \mu \mathrm{g} / \mathrm{mL})$ solution for $1 \mathrm{~h}$ in an ice bath for inhibiting endoprotease (Amin et al., 1998; Voigt et al., 1994a). To an aliquot $(0.5 \mathrm{~mL})$ of this mixture, $0.5 \mathrm{~mL}$ of sodium 
phosphate buffer was added, $0,2 \mathrm{M}$, pH 5,8 containing $5 \mathrm{mM}$ $\mathrm{Z}$-Phe-Leu-OH as substrate. The mixture was incubated at $45^{\circ} \mathrm{C}$ for $30^{\prime}$, then the reaction was stopped by adding $0.5 \mathrm{~mL}$ of TCA solution at $20 \%$, the tubes were kept for $15^{\prime}$ at room temperature and centrifuged at $10000 \times \mathrm{g}$ for 10 . The ninhydrin reaction was performed as described for the endoprotease and the activity calculated from a standard curve of leucine. One carboxypeptidase unit was considered as the amount of enzyme required to release one $\mathrm{mmol}$ of leucine per minute at pH 5.8 and $45^{\circ} \mathrm{C}$ (Misnawi et al., 2002; Hansen et al., 1998).

\section{Aminopeptidase activity determination (Pulp and Seeds)}

Aminopeptidase was extracted by incubating $30 \mathrm{mg}$ of treated powder of seeds and pulp (lyophilized) with $60 \mathrm{mg}$ of polyvinylpolypyrrolidone, $1.8 \mathrm{~mL}$ of phosphate buffer, $0.1, \mathrm{M} \mathrm{pH}$ 7.0 and $1 \%$ Triton X- 100 at $4{ }^{\circ} \mathrm{C}$. The substrate was composed of $200 \mathrm{mM}$ leucine-p-nitroaniline (H-Leu-pNA) dissolved in dimethyl sulfoxide (DMS). The incubation mixture consisted of $890 \mu \mathrm{L}$ phosphate buffer $0.1 \mathrm{M}, \mathrm{pH} 7.0,1 \%$ Triton X-100, 100 $\mu \mathrm{l}$ of the extract solution and $10 \mu \mathrm{L}$ of $200 \mathrm{mM} \mathrm{H}$-Leu-pNA. The reaction was performed for $30^{\prime}$ at $37^{\circ} \mathrm{C}$ and the absorbance measured at $405 \mathrm{~nm}$. The enzyme activity was measured in the supernatant after two ten-minute-centrifugation $(10.000$ to $20.000 \times \mathrm{g})$. The enzymatic activity was calculated from a standard curve of leucine-p-nitroaniline (Hansen et al., 1998).

Protein content determination in the extracts (Pulp and Seeds)

Protein content was determined by the method of Lowry et al. (1951), and the values were used to calculate the specific enzymatic activity.
Molds, yeasts and aerobic mesophilic count determination

The methodology used was described by the American Public Health Association (Beuchat \& Cousin, 2001).

Data analysis

All analyzes were performed with two replications in quadruplicates and the standard deviation of the data was obtained, except for the microbiological analyzes that were performed in duplicates.

\section{Results and discussion}

\subsection{Extracts proteolytic determination (Pulp and Seeds)}

The fermentation period for PH-16 cultivar was 7 days and 6 days for the TSH-1188 cultivar. Studies have shown that the time required for the seed fermentation varies according to the genetic material, but for the occurrence of major reactions that lead to the formation of the main precursors of flavor and cocoa flavor, seeds should be fermented for a period longer than five days, but not exceeding eight days (Beckett, 1994; Oetterer, 2004). In Figure 1, protease activity behavior in pulp and seed of both cultivars can be seen.

The results show that protease activity in pulp and seeds from two cultivars kept increasing until $66 \mathrm{~h}$ of fermentation, under controlled temperature conditions $\left(50^{\circ} \mathrm{C} /\right.$ pulp and $31^{\circ} \mathrm{C} /$ seed $)$, amount of substrate (final solution containing $1.5 \mathrm{mg} / \mathrm{mL}$ bovine serum albumin for pulp and seeds) and $\mathrm{pH}$ (5.7 to 3.1 for pulp and seeds) previously determined (unpublished data), after which the activity decreased.

The increase in protease activity in the first days of fermentation is due to some factors, such as those described by Levanon \& Rossetini (2001). The initial pulp conditions flavor

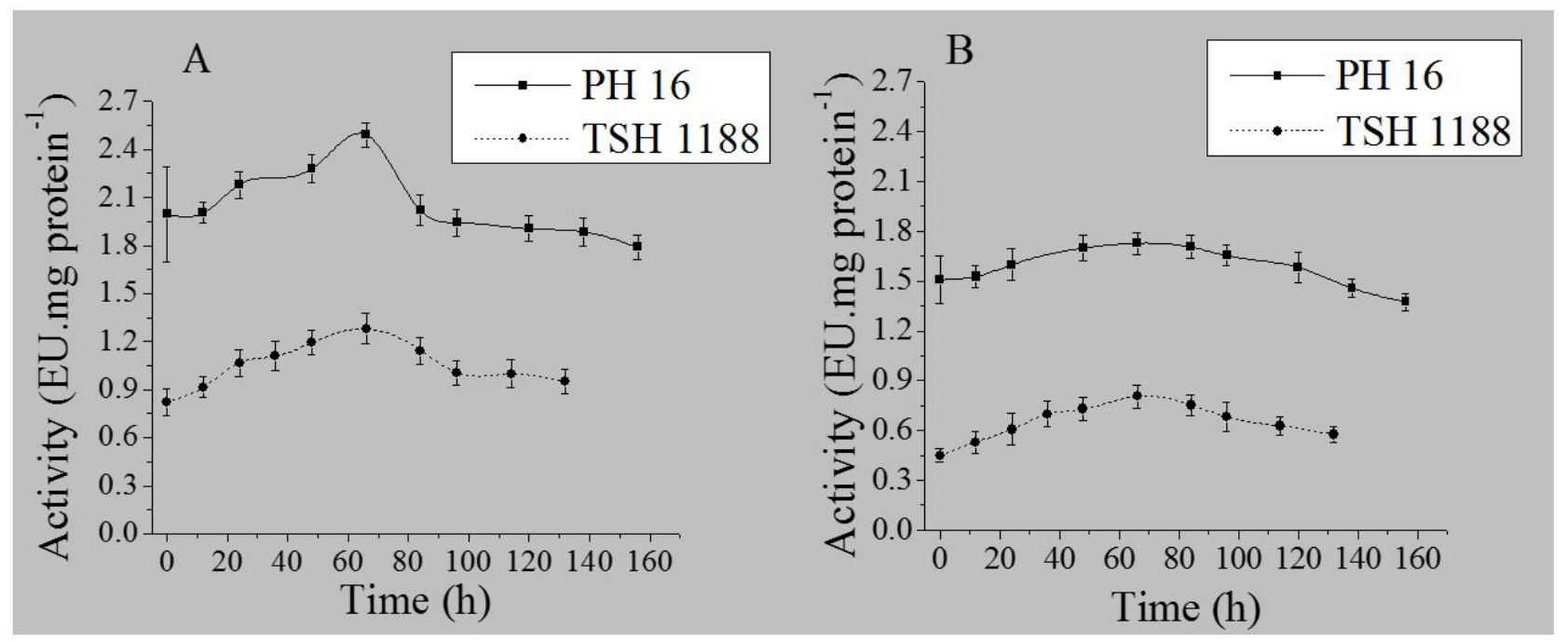

Figure 1. Protease enzyme activity in pulp and cocoa beans. (A) Pulp cultivars PH-16 and TSH-1188; (B) Seed growing PH-16 and TSH-1188. 
the rapid establishment of yeasts to multiply rapidly in the first $12 \mathrm{H}$ persisting for a period of 24 to $36 \mathrm{~h}$ in cocoa fermentation (Ardhana \& Fleet. 2003; Camu et al., 2007; Jespersen et al., 2005; Nielsen et al., 2007, Thompson et al., 2001; Schwan \& Wheals, 2004).

Studies demonstrate that yeasts convert pulp sugars into ethanol, and its presence inhibits the growth of yeasts, causing cell autolysis with consequent release of enzymes. Another important study that confirms the evidence of possible microbiotacelllysis present in cocoa beans was performed by Adeyeye et al. (2009).

In addition tomicrobial proteases, there are those which are inherent to cocoa beans (endogenous). These are activated after the cell disruption and acidification of the medium during fermentation. A minimum of 24 to $36 \mathrm{~h}$ at temperatures below $45^{\circ} \mathrm{C}$ is required for proteolysis (Biehl \& Passern, 1982).

In Figure $1 \mathrm{~A}$ and $1 \mathrm{~B}$, it is also possible to observe that proteases were more active in $\mathrm{PH}-16$ cultivar with activity values ranging from 1.79 to 2.49 UE.mg protein-1 in the pulp and 1.371 .73 UE.mg protein-1 in the seed, while the TSH-1188 cultivar ranged from 0.95 to 1.28 UE.mg protein- 1 in the pulp and seeds from 0.57 to 0.81 UE.mg protein-1. This difference may arise from genotype variations and fermentation practices (Amin et al., 1997; Biehl et al., 1982; Luna et al, 2002; Taylor, 2002; Taylor \& Roberts, 2004).

The revolving for PH16 cultivar occurred every $48 \mathrm{~h}$ and for the TSH-1188 cultivar every $24 \mathrm{~h}$, therefore, the anaerobic phase was higher in $\mathrm{PH}-16$ cultivar, which possibly promoted a greater microorganisms (yeasts) multiplication and consequently, a higher production of enzymes. According to Varnam \& Sutherland (1997), proteolytic enzymes are more active in anaerobic fermentation phase of cocoa beans. Protease microbial production follow specific conditions for each species, the medium used for fermentation, and it is subject to production differences (Abidi et al., 2008; Sandhya et al., 2005).

The maximum protease activity levels were achieved in $66 \mathrm{~h}$ of fermentation (Figure $1 \mathrm{~A}$ and $1 \mathrm{~B}$ ) for both cultivars. and the amounts at that time respectively 2.5 UE.mg protein- 1 in the pulp and 1.7 UE.mg protein-1 in the seed for PH-16 cultivar and 1.3 UE.mg protein-1 in the pulp and 0.8 UE.mg protein-1 in the seed for TSH-1188 cultivar.

The higher enzyme activity in PH-16cultivar will be possibly reflected in the proteases concentration and behavior due to numerous vital cellular processes in plants, such as protein maturation and proteolysis (Afoakwa et al., 2009; Guilloteau et al., 2005; Sánchez-Mundo et al., 2010; Thompson et al., 2001; Voigt et al., 1994a, b). Further protein degradation in cocoa fermentation after $48 \mathrm{~h}$ was found in a study conducted by Biehl et al. (1982).

The lowest protease activity in TSH-1188 cultivar in the pulp and seed, when compared to the $\mathrm{PH}-16$ cultivar, can also be related to a smaller protein degradation and membrane characteristics, which affects the entry time of organic acids formed during fermentation, and as a result, delays enzymes activtion, occurring difference in the enzymatic activity in certain genotypes (Hansen et al., 2000).

In this study, results showed that protease activity potential in the pulp is greater than in the seed for the two cultivars, showing a marked presence of the enzyme in pulp. Aquarone et al. (2001) argue that fermentation in boxes is better because it allows certain physico-chemical changes (oxidation, activation of enzymes, etc.) in the pulp. The samples analyzed were fermented in wooden boxes in agreement with that described above. Therefore, the type of fermentation process contributes positively to a greater enzyme activity mainly in the pulp.

Despite similar proteases behavior of both cultivars in pulp and seed, the reduction of protease activity in the pulp of $\mathrm{PH}-16$ cultivar after $156 \mathrm{~h}$ of fermentation was, in percentage terms, 28.21\%, (Figure 2A and 2B), when compared with the maximum activity recorded in $66 \mathrm{~h}$, whereas for the seed of same cultivar, the reduction was $20.47 \%$. In relation to TSH-1188, an activity reduction of $25.78 \%$ in the pulp was found for $132 \mathrm{~h}$ of fermentation. when combared with the maximum activitv
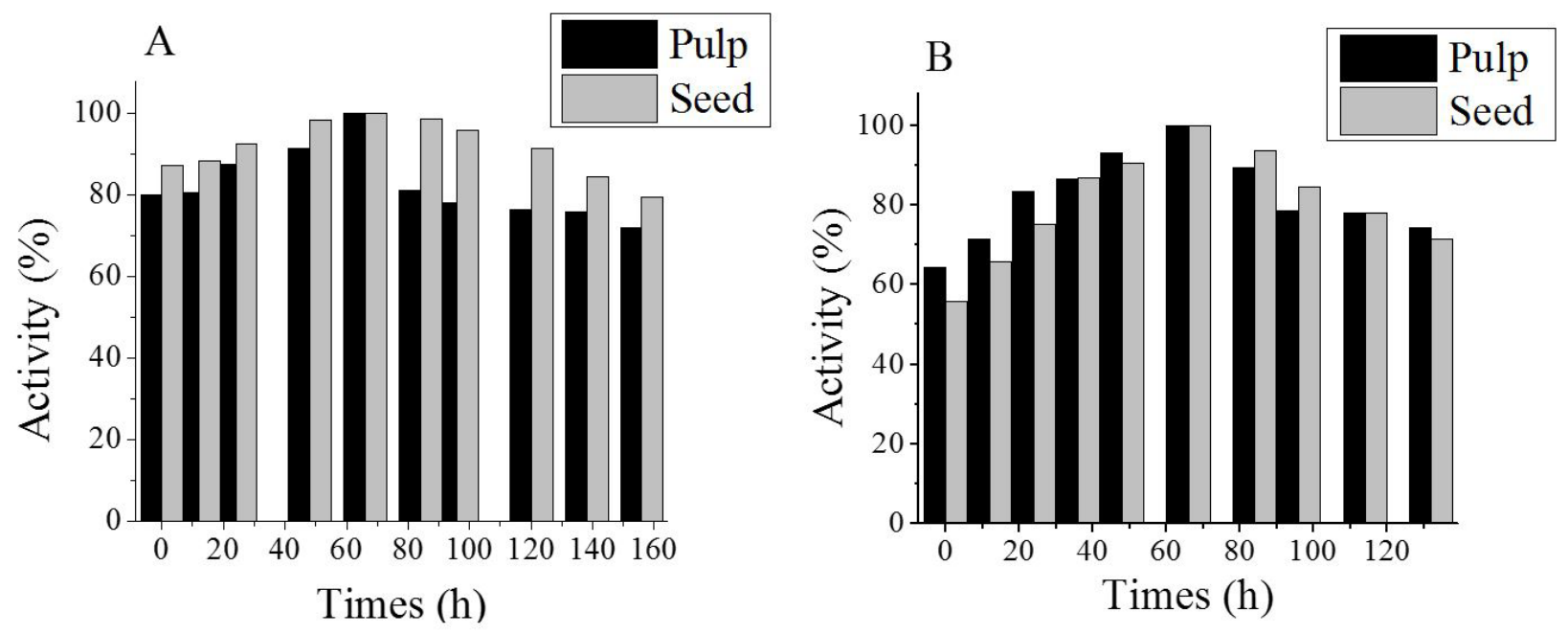

Figure 2. Percentage of reduction of enzymatic protease activity in pulp and cocoa seed. (A) PH-16 cultivar; (B) TSH-1188 cultivar. 
recorded, that was at $66 \mathrm{~h}$. As for the seed of the same cultivar, the reduction was $28.66 \%$. In the case of exogenous proteases of microbial origin, the reduction of the activity potential is linked to a rapid deactivation process as well as to the biological and physico-chemical factors during fermentation (Janssen et al., 1994; Maccheroni et al., 2004; Sanomiya \& Nahas, 2003). Another very important study that explains the likely slowdown in the protease activity in this case of endogenous origin, was carried out by Hansen et al. (8:00 pm).

\subsection{Molds, yeasts and aerobic mesophilic determination}

The results shown in Table 1 demonstrate that there was an increase in molds and yeasts counting in the first $36 \mathrm{~h}$ of fermentation for $\mathrm{PH}-16$ cultivar, and in the first $24 \mathrm{~h}$ for TSH-1188, followed by a decrease in both cases.

With reference to aerobic mesophilic counting (Table 1), the results showed a counting increase beginning at $48 \mathrm{~h}$ for $\mathrm{PH}-16$ cultivar, and at $36 \mathrm{~h}$ for TSH-1188. The decrease in microbial load related to molds and yeasts followed by the increase of aerobic mesophilic counting for both cultivars coincides with the beginning of the revolving process (cocoa mass oxygenation in fermentation).

Studies have demonstrated the predominance of yeasts and molds in the early stages of fermentation (24-36h). However, with the production of alcohol by them and the aeration, death of the fungi occurs, allowing bacteria proliferation, which, in spite of being already present since the beginning of fermentation, only becomes dominant at that moment (Camu et al., 2007; Schwan \& Wheals, 2004; De Vuyst et al., 2010).

\subsection{Determination of isoenzyme extracts}

The studied isoenzymes showed similar activity profiles in both cultivars (PH-16 and TSH-1188) both in pulp and seed, proving to be active throughout the entire cocoa fermentation process, despite showing a decrease in activity.

In regards to aminopeptidase (Figure $3 \mathrm{~A}$ ) the values of activity in PH-16 cultivarranged from 0.62 to 0.07 g-units 1 Dry degreased weight- PSD (pulp) and from 0.68 to 0.08 units g- 1PSD (seed) and in TSH-1188 cultivar from 0.64 to 0.07 units g-1PSD (pulp) and from 0.68 to $0.068 \mathrm{~g}$ 1-PSD units (seed), a slight
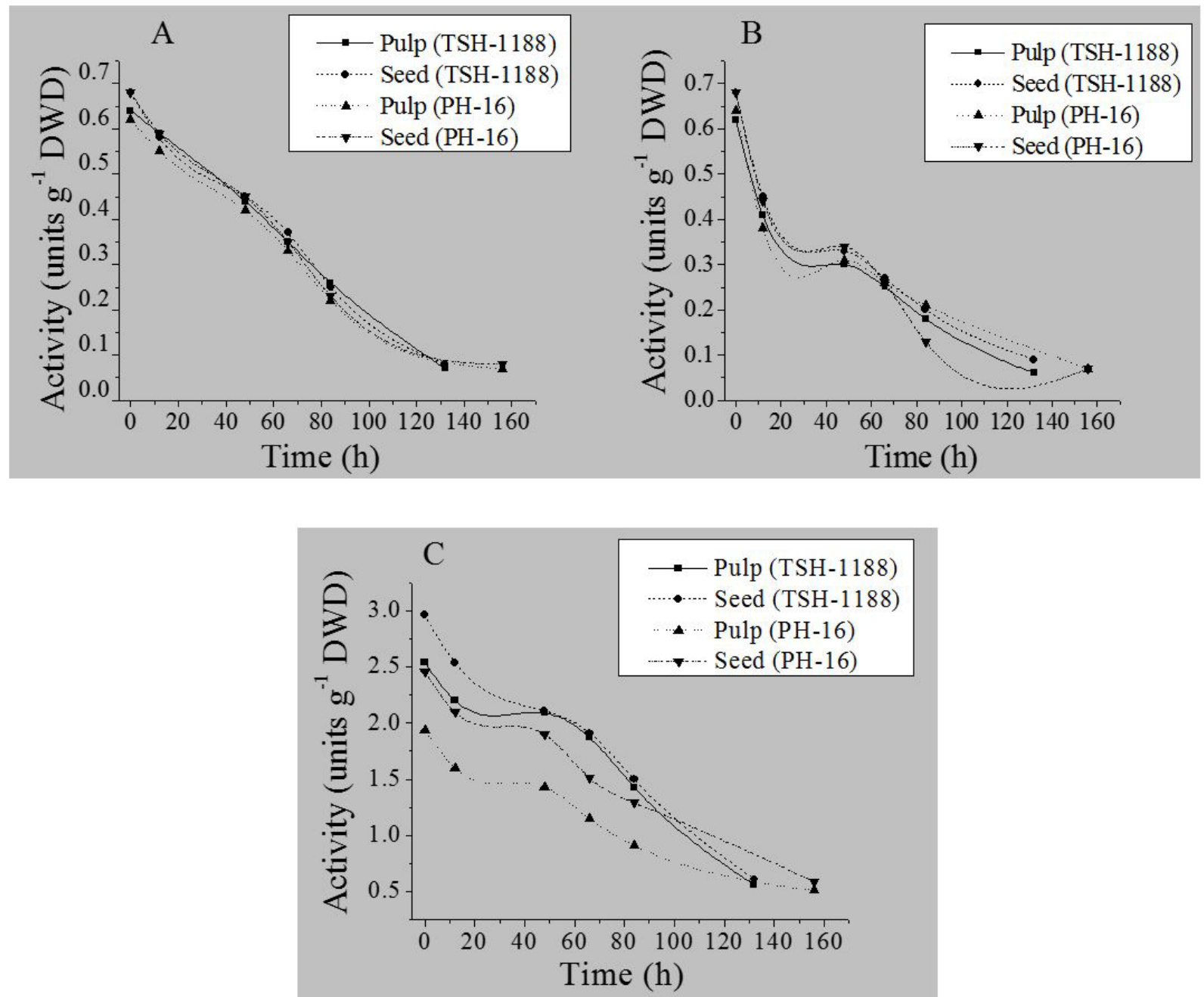

Figure 3. Isoenzymes activity in pulp and seed of two cocoa varieties. (A) Aminopeptidase; (B) Carboxypeptidase; (C) Endoprotease. 
Table 1. Molds, yeasts and aerobic mesophilic counting.

\begin{tabular}{cccccc}
\hline \multirow{2}{*}{ Time (h) } & \multicolumn{2}{c}{ Bacteria $($ CFU/g) } & \multicolumn{2}{c}{ Yeasts and Molds (CFU/g) } \\
\cline { 2 - 3 } \cline { 5 - 6 } & PH 16 & TSH 1188 & & PH 16 & TSH 1188 \\
\hline Beginning & $2.4 \times 10^{3}$ & $2.0 \times 10^{3}$ & & $3.6 \times 10^{3}$ & $3.4 \times 10^{3}$ \\
12 & $2.0 \times 10^{3}$ & $1.7 \times 10^{3}$ & & $4.0 \times 10^{4}$ & $3.9 \times 10^{4}$ \\
24 & $2.1 \times 10^{3}$ & $1.9 \times 10^{3}$ & & $5.7 \times 10^{5}$ & $5.6 \times 10^{5}$ \\
36 & $4.0 \times 10^{3}$ & $3.2 \times 10^{4}$ & & $6.0 \times 10^{5}$ & $4.6 \times 10^{3}$ \\
48 & $5.1 \times 10^{4}$ & $4.9 \times 10^{4}$ & & $2.8 \times 10^{3}$ & $<1.0 \times 10^{2}$ \\
66 & $5.8 \times 10^{5}$ & $5.7 \times 10^{5}$ & & $<1.0 \times 10^{2}$ & $<1.0 \times 10^{2}$ \\
84 & $5.3 \times 10^{5}$ & $5.0 \times 10^{6}$ & & $<1.0 \times 10^{2}$ & $<1.0 \times 10^{2}$ \\
96 & $4.7 \times 10^{6}$ & $4.5 \times 10^{6}$ & & $<1.0 \times 10^{2}$ & $<1.0 \times 10^{2}$ \\
114 & & $4.0 \times 10^{5}$ & & $<1.0 \times 10^{2}$ \\
120 & $4.3 \times 10^{5}$ & & $<1.0 \times 10^{2}$ & \\
132 & & $4.2 \times 10^{5}$ & & $<1.0 \times 10^{2}$ \\
138 & $4.6 \times 10^{6}$ & & $0.8 \times 10^{2}$ & \\
156 & $5.3 \times 10^{5}$ & & $1.0 \times 10^{2}$ & \\
\hline
\end{tabular}

difference in aminopeptidase activity and behavior in pulp and seeds of both cultivars. The activity values in this study decreased during the fermentation process, being in line with the report of Hansen et al. (1998) and Hansen et al. (2000).

Regarding carboxypeptidase activity (Figure 3B) for PH-16 cultivar, values between 0.68 and 0.07 g-1PSD units (pulp) between 0.64 and $0.07 \mathrm{~g}$-1PSD units (seed) and for TSH-1188 cultivar 0.68 to 0.09 g-1PSD units (pulp) and 0.62 to $0.06 \mathrm{~g}$-1PSD units (seed) were shown, similar behavior for both cultivars and values differed little, despite a milder reduction in carboxypeptidase in relation to aminopeptidase. Hansen et al. (2000) also reports that carboxypeptidase is partially inactivated during fermentation. Another study by Hansen et al. (1998) demonstrates activity initial value below the value found in this study. However, enzyme inactivation was presented with final results closer to those found in this work.

As for endoprotease activity (Figure $3 \mathrm{C}$ ), the results ranged from 1.94 to $0.51 \mathrm{~g}$-1PSD units (pulp) and from 2.46 to $0.59 \mathrm{~g}$-1PSD units (seed) for cultivar PH-116 and from 2.54 to $0.56 \mathrm{~g}$-1PSD units (pulp) and from 2.96 to $0.61 \mathrm{~g}$-1PSD units (seed) for the TSH-1188 cultivar. Therefore, higher activity values were obtained for TSH-1188 cultivar, thus demonstrating greater concentration of endoprotease enzyme in this cultivar. Hansen et al. (2000) report that endo glycosidases remain active throughout the cocoa fermentation process, displaying different stabilities, particularly with regards to inactivation, being therefore, more resistant to heat, to the presence of acids or action of polyphenols.

\section{Conclusions}

A difference was seen regarding proteases activity potential in both cultivars (PH-16 and TSH-1188) in pulp and seed, despite showing similar behavior with increasing activity up to $66 \mathrm{~h}$ of fermentation and subsequent decrease in enzyme activity. The activity increase $y$ in the early days coincides with the period of microorganisms growth especially fungi and yeast (anaerobic stage).
Protease was more active in the pulp of $\mathrm{PH}-16$ cultivar. Aminopeptidase and carboxypeptidase activity behavior was similar for both cultivars in the pulp and seed. However, endoprotease behavior was a bit different for TSH-1188 cultivar showing higher activity values for that cultivar, both in pulp and in seed. Results for molds, yeasts and aerobic mesophilic bacterium counting indicate that the period after the reduction of molds and yeast counting is consistent with the period of increased activity of proteases, thus enabling the production of these by those micro-organisms.

\section{Acknowledgements}

The authors thank the National Council for Scientific and Technological Development (CNPq), the Higher Education Personnel Improvement Coordination (CAPES), the Bahia State Research Foundation (FAPESB) for financial support, Fazenda Lajedo do Ouro for the samples availability and a great friend Joailton Ventura da Conceição.

\section{References}

Abidi, F., Limam, F., \& Nejib, M. M. (2008). Production of alkaline proteases by Botrytis cinerea using economic raw materials: Assay as biodetergent. Process Biochemistry, 43(11), 1202-1208. http:// dx.doi.org/10.1016/j.procbio.2008.06.018.

Adeyeye, E. I., Akinyeye, R. O., Ogunlade, I., Olaofe, O., \& Boluwade, J. O. (2009). Effect of farm and industrial processing on the amino acid profile of cocoa beans. Food Chemistry, 118(2), 357-363. http:// dx.doi.org/10.1016/j.foodchem.2009.04.127.

Afoakwa, E. O., Paterson, A., Fowler, M., \& Ryan, A. (2008). Flavor formation and character in cocoa and chocolate: a critical review. Critical Reviews in Food Science and Nutrition, 48(9), 840-857. http:// dx.doi.org/10.1080/10408390701719272.

Afoakwa, E. O., Paterson, A., Fowler, M., \& Ryan, A. (2009). Matrix effects on flavour volatiles release in dark chocolates varying in particle size distribution and fat content using GC-mass spectrometry and GC-olfactometry. Food Chemistry, 113(1), 208-215. http://dx.doi. org/10.1016/j.foodchem.2008.07.088.

Amin, I., Jinap, S., \& Jamilah, B. (1997). Vicilin-class globulin and their degradation during cocoa fermentation. Food Chemistry, 59, 1-5.

Amin, I., Jinap, S., \& Jamilah, B. (1998). Proteolytic Activity (Aspartic Endoproteinase and Carboxypeptidase) of Cocoa Bean during fermentation. Journal of the Science of Food and Agriculture, 76(1), 123 128. http://dx.doi.org/10.1002/(SICI)1097-0010(199801)76:1<123::AIDJSFA917>3.0.CO;2-N.

Aquarone, E., Borzani, W., Schmidell, W., \& Lima, U. A. (2001). Biotecnologia industrial (Vol. 4). São Paulo: Edgard Blucher.

Ardhana, M. M., \& Fleet, G. H. (2003). The microbial ecology of cocoa bean fermentations in Indonesia. International Journal of Food Microbiology, 86(1-2), 87-99. PMid:12892924. http://dx.doi. org/10.1016/S0168-1605(03)00081-3.

Beckett, S. T. (1994). Fabricación y utlización industrial del chocolate (p. 432). Zaragoza: Editorial Acribica.

Beckett, S. T. (2009). Industrial chocolate manufacture and use (4th ed., 732 p.). London: Blackwell Publishing Ltd.

Beuchat, L. R., \& Cousin, M. A. (2001). Yeasts and molds. In American Public Health Association - APHA. Compendium of methods for the microbiological examination of foods (4th ed., Chap. 20). Washington: APHA. 
Biehl, B., \& Passern, D. (1982). Proteolysis during fermentation like incubation of cocoa seed. Journal of the Science of Food and Agriculture, 33(12), 1280-1290. http://dx.doi.org/10.1002/jsfa.2740331215.

Biehl, B., Wewetzer, C., \& Passern, D. (1982). Vacuolar (storage) protein of cocoa seeds and their degradation during germination and fermentation. Journal of Science of Food and Agriculture, London, 33(12), 1291-1304. http://dx.doi.org/10.1002/jsfa.2740331216.

Bucheli, P., Kanchanomai, C., \& Meyer, I. (2000). Strategy for assessing cocoa flavour of a large number of samples for selection and breeding. In Proceedings of 13th International Cocoa Research Conference, Kata Kinobalu, Sabah, Malaysia.

Camu, N., De Winter, T., Addo, S. K., Takrama, J. S., Bernaert, H., \& De Vuyst, L. (2008a). Fermentation of cocoa beans: influence of microbial activities and polyphenol concentrations on the flavor of chocolate. Journal of Science of Food and Agriculture, 88(13), 2288-2297. http://dx.doi.org/10.1002/jsfa.3349.

Camu, N., De Winter, T., Verbrugghe, K., Cleenwerck, I., Vandamme, P., Takrama, J. S., Vancanneyt, M., \& De Vuyst, L. (2007). Dynamics and biodiversity of populations of lactic acid bacteria and acetic acid bacteria involved in spontaneous heap fermentation of cocoa beans in Ghana. Applied Environmental Microbiology, 73(6), 1809-1824. http://dx.doi.org/10.1128/AEM.02189-06.

Camu, N., González, Á., De Winter, T., Van Schoor, A., De Bruyne, K., Vandamme, P., Takrama, J. S., Addo, S. K., De Vuyst, L. (2008b). Influence of turning and environmental contamination on the dynamics of populations of lactic acid and acetic acid bacteria involved in spontaneous cocoa bean heap fermentation in Ghana. Applied Environmental Microbiology, 74(1), 86-98. http://dx.doi. org/10.1128/AEM.01512-07.

Cruz, J. F. M., Leite, P. B., Soares, S. E., \& Bispo, E. S. (2013). Assessment of the fermentative process from different cocoa cultivars produced in Southern Bahia, Brazil. African Journal of Biotechnology, 12(33), 5218-5225. http://dx.doi.org/10.5897/AJB2013.12122.

Daniel, H. M., Vrancken, G., Takrama, J. F., Camu, N., De Vos, P., \& De Vuyst, L. (2009). Yeast diversity of Ghanaian cocoa bean heap fermentations. FEMS Yeast Research, 9, 774-783.

De Vuyst, L., Lefeber, T., Papalexandratou, Z., Camu, N. (2010). The functional role of lactic acid bacteria in cocoa bean fermentation. In F. Mozzi, R. R. Raya \& G. M. Vignolo (Eds.), Biotechnology of lactic acid bacteria: novel applications (pp. 301-326). Ames: Wiley-Blackwell.

Deuner, S., Ferreira, L. S., Bacarin, M. A., Bervald, C. M. P., \& Zanatta, E. R. (2005). Caracterização parcial da invertase ácida solúvel em tubérculos de batata: energia de ativação e efeito de inibidores. Revista Brasileira de Agrociência, 11(1), 45-50. http://dx.doi.org/10.18539/ CAST.V11I1.1166.

Efraim, P., Tucci, M. L., \& Pezoa-Garcia, N. H. (2006). Teores de compostos fenólicos de sementes de cacaueiro de diferentes genótipos. Brazilian Journal of Food Technology, 9(4), 229-236.

Fowler, M. S. (2009). Cocoa beans: from tree to factory. In S. T. Beckett (Ed.), Industrial chocolate manufacture and use (4th ed., pp. 10-47). Oxford: Blackwell Science.

Garcia-Armisen, T., Papalexandratou, Z., Hendryckx, H., Camu, N., Vrancken, G., De Vuyst, L. , \& Cornelis, P. (2010). Diversity of the total bacterial community associate dwith Ghanaian and Brazilian cocoa bean fermentation samples as revealed by a $16 \mathrm{~S}$ rRNA gene clone library. Applied Microbiology and Biotechnology, 87(6), 22812292. PMID: 20559826. http://dx.doi.org/10.1007/s00253-010-2698-9.

Giongo, J. L. (2006). Caracterização e aplicação de proteases produzidas por linhagens de Bacillus sp. (Dissertação de mestrado). Universidade Federal do Rio Grande do Sul, Porto Alegre.
Gomez, M. L. P. A., Lajolo, F. M., \& Cordenunsi, B. R. (1999). Metabolismo de carboidratos durante o amadurecimento do mamão (Caricapapaya L. cv. Solo): influência da radiação gama. Ciência e Tecnologia de Alimentos, 19(2), 246-252.

Guilloteau, M., Lalaoi, M., Michaux, S., Bucheli, P., \& McCarthy, J. (2005). Identification and characterization of the majoraspartic proteinase activity in Theobroma cacao Seeds. Journal of the Science of Food and Agriculture, 85(4), 549-562. http://dx.doi.org/10.1002/jsfa.1777.

Hansen, C. E., Del Olmo, M., \& Burri, C. (1998). Enzyme activities in cocoa beans during fermentation. Journal of the Science of Food and Agriculture, 77(2), 273-281. http://dx.doi.org/10.1002/(SICI)10970010(199806)77:2<273::AID-JSFA40>3.0.CO;2-M.

Hansen, C. E., Mañez, A., Burri, C., \& Bousbaine, A. (2000). Comparison of enzyme activities involved in flavour precursos formation in unfermented beans of different cocoa genotypes. Journal of the Science of Food and Agriculture, 80(8), 1193-1198. http://dx.doi. org/10.1002/1097-0010(200006)80:8<1193::AID-JSFA619>3.0.CO;2-7.

Huang, Y., \& Barringer, S. A. (2010). Alkylpyrazines and other volatiles in cocoa liquors at ph 5 to 8 , by selected ion flow Tube-Mass Spectrometry (SIFT-MS). Journal of Food Science, 75(1), C121-C127. PMid:20492142. http://dx.doi.org/10.1111/j.1750-3841.2009.01455.x.

Janssen, P. H., Peek, K., \& Morgan, H. W. (1994). Effect of culture conditions on the production of an extracellular proteinase by Thermus sp. Rt41A. Applied Microbiology and Biotechnology, 41(4), 400-406. http://dx.doi.org/10.1007/s002530050164.

Jespersen, L., Nielsen, D. S., Honholt, S., \& Jakobsen, M. (2005). Occurrence and diversity of yeast involved in fermentation of West African cocoa beans. FEMS Yeast Research, 5(4-5), 441-453. PMid:15691749. http://dx.doi.org/10.1016/j.femsyr.2004.11.002.

Levanon, Y., \& Rossetini, S. M. O. (2001). Cacau. In E. Aquarone, W. Borzani, W. Schmidell \& U. A. Lima. Biotecnologia industrial: biotecnologia na produção de alimentos (Vol. 4, pp. 387-420). São Paulo: Edgard Blucher.

Lopes, U. V., Monteiro, W. R., Pires, J. L., Clement, D., Yamada, M. M., \& Gramacho, K. P. (2011). Cacao breeding in Bahia, Brazil - strategies and results. Crop Breeding and Applied Biotechnology, 1, 73-81.

Lowry, O. H., Rosebrough, N. J., Farr, A. L., \& Randall, R. J. (1951). Protein measurement with the Folin phenol reagent. The Journal of Biological Chemistry, 193(1), 265-275. PMid:14907713.

Luna, F., Crouzillat, D., Cirou, L., \& Bucheli, P. (2002). Chemial composition and flavor of Ecuadorian cocoa liquor. Journal of Agricultural an Food Chemistry, 50(12), 3527-3532. PMid:12033823. http://dx.doi.org/10.1021/jf0116597.

Maccheroni, W., Jr., Araújo, W. L., \& Azevedo, J. L. (2004). Ambient $\mathrm{pH}$-regulated enzyme secretion in endophytic and pathogenic isolates of the fungal genus Colletotrichum. Scientia Agricola, 61(3), 298-302. http://dx.doi.org/10.1590/S0103-90162004000300010.

Misnawi, S. J., Nazamid, S., \& Jamilah, B. (2002). Activation of remaining key enzymes in dried under-fermented cocoa beans and its effect on aroma precursor formation. Food Chemistry, 78(4), 407-417. http://dx.doi.org/10.1016/S0308-8146(02)00120-6.

Nielsen, D. S., Teniola, O. D., Ban-Koffi, L., Owusu, M., Andersson, T. S., \& Holzapfel, W. H. (2007). The microbiology of Ghanaian cocoa fermentations analysed using culture-dependent and cultureindependent methods. International Journal of Food Microbiology, 114(2), 168-186. PMID: 17161485. http://dx.doi.org/10.1016/j. ijfoodmicro.2006.09.010.

Oetterer, M. (2004). Tecnologias de obtenção do cacau e do chocolate. Piracicaba: Escola Superior de Agricultura Luiz de Queiroz, 
Universidade de São Paulo. Retrieved from http:// www.esalq.usp. br/departamento/lan/pdf/cacau\%20chocolate.pdf

Papalexandratou, Z., Camu, N., Falony, G., \& De Vuyst, L. (2011a). Comparison of the bacterial species diversity of spontaneous cocoa bean fermentations carried out at selected farms in Ivory Coast and Brazil. Food Microbiology, 28(5), 964 973. http://dx.doi.org/10.1016/j. fm.2011.01.010.

Papalexandratou, Z., Falony, G., Romanens, E., Jimenez, J. C., Amores, F., Daniel, H. M., \& De Vuyst, L. (2011b). Species diversity, community dynamics, and metabolite kinetics of the microbiota associated with traditional Ecuadorian spontaneous cocoa bean fermentations. Applied and Environmental Microbiology, 77, 7698-7714. PMID: 21926224. http://dx.doi.org/10.1128/AEM.05523-11.

Papalexandratou, Z., Vrancken, G., De Bruyne, K., Vandamme, P., \& De Vuyst, L. (2011c). Spontaneous organic cocoa bean fermentations in Brazil are characterized by a restricted species diversity of lactic acid bacteria and acetic acid bacteria. Food Microbiology, 28(7), 13261338. PMID: 21839382. http://dx.doi.org/10.1016/j.fm.2011.06.003.

Sánchez-Mundo, M. L., Bautista-Munoz, C., \& Jaramillo-Flores, M. E. (2010). Characterization of the exopeptidase activity existing in Theobroma cacao L. during germination. Process Biochemistry, 45(7), 1156-1162. http://dx.doi.org/10.1016/j.procbio.2010.04.012.

Sandhya, C., Sumantha, A., Szakacs, G., \& Pandey, A. (2005). Comparative evaluation of neutral protease production by Aspergillus oryzae in submerged and solid-state fermentation. Process Biochemistry, 40(8), 2689-2694.

Sanomiya, L. T., \& Nahas, E. (2003). Microorganismos produtores de hidrolases envolvidos nas transformações dos compostos do carbono e do nitrogênio do solo. Ciência Rural, 33(5), 835-842. http://dx.doi. org/10.1590/S0103-84782003000500007.

Schwan, R. F. (1998). Cocoa fermentations conduced with a defined microbial cocktail inoculum. Applied and Environmental Microbiology, 64(4), 1477-1483.

Schwan, R. F., \& Wheals, A. E. (2004). The microbiology of cocoa fermentation and its role in chocolate quality. Critical Reviews in Food Science and Nutrition, 44(4), 205-221. PMid:15462126. http:// dx.doi.org/10.1080/10408690490464104.
Silva, M. R. O., Santiago, A. L. C. M. A., Souza, P. M., Correia, J., SouzaMotta, C., Moreira, K. A., Porto, A. L. F., \& Lima, J. L., Fo. (2003). Estudo de métodos de extração de protease termostável produzida pelo Penicillium aurantiogriseum. In Anais do XIV Simpósio Nacional de Fermentações, Florianópolis, Santa Catarina.

Taylor, A. J. (2002). Food flavor technology. Sheffield: Sheffield Academic Press.

Taylor, A. J., \& Roberts, D. D. (2004). Flavour perception. Engeland: Oxford Blackwell Publishing.

Thompson, S. S., Miller, K. B., \& Lopez, A. S. (2001). Cocoa and coffee. In M. P. Doyle, L. R. Beuchat \& T. J. Montville (Eds.), Food microbiology fundamentals and frontiers (pp. 721-736). Washington: ASM Press.

Thompson, S. S., Miller, K. B., Lopez, A., \& Camu, N. (2013). Cocoa and coffee. In M. P. Doyle, L. R. Beuchat \& T. J. Montville (Eds.), Food microbiology: fundamentals and frontiers (4th ed., pp. 881-899). Washington: ASM Press.

Varnam, A. H., \& Sutherland, J. P. (1997). Bebidas: tecnología, química e microbiologia. Zaragoza: Acribia.

Voigt, J., Biehl, B., Heinrichs, H., Kamaruddin, S., Marsoner, G. G., \& Hugi, A. (1994a). In-vitro formation of cocoa-specific aroma precursors: aroma-related peptides generated from cocoa-seed protein by co-operation of an aspartic endoprotease and a carboxypeptidase. Food Chemistry, 49(2), 173-180. http://dx.doi.org/10.1016/03088146(94)90155-4.

Voigt, J., Heinrichs, H., Voigt, G., \& Biehl, B. (1994b). Cocoa-specific aroma precursors are generated by proteolytic digestion of the vicilin-like globulin of cocoa seeds. Food Chemistry, 50(2), 177-184. http://dx.doi.org/10.1016/0308-8146(94)90117-1.

Wood, G. A. R., \& Lass, R. A. (2001). Cocoa (4th ed.). Oxford: Blackwell Science.

Yusep, I., Jinap, S., Jamilah, B., \& Nazamid, S. (2002). Influence of carboxypeptidases on free aminoacid, peptide and methylpyrazine contents of under-fermented cocoa beans. Journal of the Science of Food and Agriculture, 82(13), 1584-1592. http://dx.doi.org/10.1002/ jsfa.1232. 